\title{
Cowpea development under different temperatures and carbon dioxide concentrations ${ }^{1}$
}

\author{
Francislene Angelotti ${ }^{2}$, Laise Guerra Barbosa ${ }^{2}$, \\ Juliane Rafaele Alves Barros ${ }^{3}$, Carlos Antonio Fernandes dos Santos ${ }^{2}$
}

\section{ABSTRACT}

The increase of $\mathrm{CO}_{2}$ concentrations and temperatures may affect the plant development and production. This study aimed to evaluate the impact of the increased temperature and carbon dioxide concentration on the development of cowpea cultivars. The experiment was conducted in growth chambers, with control of $\mathrm{CO}_{2}$ and temperature. A completely randomized design was carried out, in a $4 \times 3 \times 2$ factorial arrangement [cultivar $\mathrm{x}$ temperature (day/night) $\mathrm{x} \mathrm{CO}_{2}$ ], with three replicates. The duration of the cowpea vegetative and reproductive phases was evaluated and, at the end of the experiment, the number of pods per plant, number of grains per pod, seed weight, shoot fresh and dry matter weight were quantified. Temperature affects the development of cowpea cultivars, and the temperatures of $29{ }^{\circ} \mathrm{C}$ (day) $/ 23{ }^{\circ} \mathrm{C}$ (night) lead to a higher seed weight. The increase of $\mathrm{CO}_{2}$ leads to a higher number of pods and seeds and seed weight. The BRS Tapaihum cultivar presented the highest number of pods and seeds and seed weight. In addition, the temperatures of $32{ }^{\circ} \mathrm{C}$ (day) $/ 29^{\circ} \mathrm{C}$ (night) lead to a greater flower abortion in the BRS Pujante and BRS Tapaihum cultivars.

KEYWORDS: Vigna unguiculata, climate change, phenology.

\section{INTRODUCTION}

Climate changes over time have stood out as a global concern and are among the challenges of food security. According to the Intergovernmental Panel on Climate Change (IPCC 2013), the concentration of greenhouse gases has increased since 1750, due to human activity. In 2017, the concentration of carbon dioxide $\left(\mathrm{CO}_{2}\right)$ reached 409 parts per million (ppm), surpassing pre-industrial levels by about $40 \%$ (Tans \& Keeling 2017). This has directly influenced

\section{RESUMO}

Desenvolvimento de feijão-caupi sob diferentes temperaturas e concentrações de dióxido de carbono

O aumento dos níveis de $\mathrm{CO}_{2}$ e da temperatura podem afetar o crescimento e a produtividade das plantas. Objetivou-se avaliar o impacto do aumento da concentração de dióxido de carbono e da temperatura no desenvolvimento de cultivares de feijão-caupi. O experimento foi conduzido em câmaras de crescimento, com controle de $\mathrm{CO}_{2}$ e temperatura. O delineamento experimental foi inteiramente casualizado, em arranjo fatorial $4 \times 3 \times 2$ [cultivar x temperatura (diurna/noturna) $\mathrm{x} \mathrm{CO}_{2}$ ], com três repetições. Foi avaliada a duração das fases vegetativa e reprodutiva do feijão-caupi e, ao final do experimento, quantificado o número de vagens por planta, número de grãos por vagem, peso das sementes, peso da matéria fresca e seca da parte aérea. A temperatura afeta o desenvolvimento das cultivares de feijão-caupi, sendo que as temperaturas de $29{ }^{\circ} \mathrm{C}$ (dia) $/ 23{ }^{\circ} \mathrm{C}$ (noite) proporcionam sementes com maior peso. $\mathrm{O}$ aumento de $\mathrm{CO}_{2}$ incrementa o número de vagens e de sementes e o peso das sementes. A cultivar BRS Tapaihum apresentou maior número de vagens e de sementes e peso de sementes. Além disso, as temperaturas de $32{ }^{\circ} \mathrm{C}$ (dia) $/ 29^{\circ} \mathrm{C}$ (noite) provocam maior abortamento de flores nas cultivares BRS Pujante e BRS Tapaihum.

PALAVRAS-CHAVE: Vigna unguiculata, mudanças climáticas, fenologia.

the increase in the air temperature, and studies indicate that the average atmosphere temperature increased around $0.85^{\circ} \mathrm{C}$ from 1880 to 2012 (IPCC 2013).

Agricultural research focused on food security needs advances to understand the impacts of climate change on agriculture, since the cropping systems are submitted to a series of environmental factors that, directly or indirectly, may compromise their productivity (Challinor et al. 2014). Thus, vulnerability studies are extremely important for agriculture, in

1. Received: July 05, 2019. Accepted: Nov. 11, 2019. Published: Mar. 27, 2020. DOI: 10.1590/1983-40632020v5059377.

2. Empresa Brasileira de Pesquisa Agropecuária (Embrapa Semiárido), Petrolina, PE, Brasil.

E-mail/ORCID: francislene.angelotti@embrapa.br/0000-0001-7869-7264, carlos-fernandes.santos@embrapa.br/ 0000-0002-6932-6805, laise_guerra@hotmail.com/0000-0002-2562-6523.

3. Universidade Estadual de Feira de Santana, Feira de Santana, BA, Brasil. E-mail/ORCID: juliane-ab@hotmail.com/0000-0002-0408-0904. 
order to implement adaptation measures. The increase of $\mathrm{CO}_{2}$ concentration may lead to a higher plant production, as a function of the higher photosynthetic activity, decreasing photorespiration and transpiration rates (Walter et al. 2015). These changes may vary with the species, depending on the different photosynthetic routes, genotypes, environment and their phenotypic interaction, growth rate and other characteristics. However, as temperatures rise, plants can reduce the metabolic activity and increase respiration, directly influencing their growth and development (Hatfield \& Prueger 2015). High temperatures cause an imbalance in the absorption and elimination of $\mathrm{CO}_{2}$ by plants (Martinez et al. 2015). In addition, changes in day/night temperatures interfere with the circadian cycle, with direct impact on stomatal movement, enzymatic activity, flowering, photosynthesis and plant senescence (Srivastava et al. 2019).

In this way, it is understood that studies on the impact of the interaction between different environmental components, such as temperature and $\mathrm{CO}_{2}$, and its repercussions on the cowpea [Vigna unguiculata (L.) Walp.] production are relevant themes, due to the socioeconomic importance of this crop for the Northeast and North regions of Brazil. However, there are no reports in Brazil about the influence of increased $\mathrm{CO}_{2}$ concentration and temperature on cowpea.

This legume is a warm-season crop adapted to many areas of the humid tropics and temperate zones, with development in a wide temperature range between $18{ }^{\circ} \mathrm{C}$ and $37{ }^{\circ} \mathrm{C}$ (Vale et al. 2017). Thus, studies evaluating the vulnerability of cowpea cultivars, allowing the recommendation and combining resilience and precocity with productivity, as a way to mitigate problems arising from temperature increases, are strategic for agriculture (Aliyu et al. 2019). In this way, this study aimed to evaluate the impact of increased $\mathrm{CO}_{2}$ concentrations and temperatures on the development and yield of different cowpea cultivars.

\section{MATERIAL AND METHODS}

The experiment was carried out at the Embrapa Semiárido (Petrolina, Pernambuco state, Brazil), in growth chambers, with control of $\mathrm{CO}_{2}$, temperature, humidity and photoperiod, from March to November 2013.

Cowpea seeds (Canapu, BRS Marataoã, BRS Pujante and BRS Tapaihum cultivars) were planted in $10-\mathrm{L}$ pots, in a $4 \times 3 \times 2$ factorial arrangement (cultivar $\mathrm{x}$ temperature $\mathrm{x} \mathrm{CO}_{2}$ concentration), with three replicates. A total of 12 seeds per pot, containing soil + organic fertilizer in a $2: 1$ ratio, were sown. Thinning was carried out at 10 days after sowing, when the plants presented fully expanded primary leaves, leaving four plants per replicate, with nitrogen fertilization carried out at 23 days after the plant germination (Freire Filho et al. 2005).

Three temperature regimes (day/night) were used $\left(26{ }^{\circ} \mathrm{C} / 20{ }^{\circ} \mathrm{C}, 29{ }^{\circ} \mathrm{C} / 23{ }^{\circ} \mathrm{C}\right.$ and $\left.32{ }^{\circ} \mathrm{C} / 29^{\circ} \mathrm{C}\right)$, as well as two $\mathrm{CO}_{2}$ concentrations $(370 \mathrm{ppm}$ and $550 \mathrm{ppm}$ ), with a photoperiod of $13 \mathrm{~h}$. The evaluated temperatures were defined based on the IPCC and the air temperature increases over the average temperature of the region (approximately $26{ }^{\circ} \mathrm{C}$ ), combined with two $\mathrm{CO}_{2}$ concentrations, corresponding to the current and predicted concentration for 2050 . Two growth chambers were used: the first with a concentration of $370 \mathrm{ppm}$ of $\mathrm{CO}_{2}$ and the second with $550 \mathrm{ppm}$ of $\mathrm{CO}_{2}$, and only the temperature of each stage was variable, with approximately 90 days in length. The $\mathrm{CO}_{2}$ concentration inside the chambers was monitored with the aid of the Sitrad software.

For percentage of flower abortion, the number of aborted flower buds per plant was daily counted. For the phenological description, the phenological stages presented by each plant were daily recorded. The change of stage was considered when a new leaflet was completely open. The cowpea vegetative and reproductive stages were adapted from the Fancelli's scale (2009), with the following description: V3 - first trifoliate leaf; V4 - third trifoliate leaf; R5 - flower buds; R6 - first flower opening; R7 - appearance of the first pod; R8 - first full pods; R9 - modification of pod color (physiological maturity).

The number of pods per plant, number of grains per pod and weight of seeds harvested at the R9 maturity stage were quantified. The shoot fresh mass (g) was measured at the end of the experiment, by weighing the material in an analytical scale with $0.001 \mathrm{~g}$ precision. For plant dry matter, the plants were conditioned in a forced circulation oven at $60{ }^{\circ} \mathrm{C}$, for a period of three days, and then weighed to obtain the dry weight.

The data were subjected to the Shapiro-Wilk test at 0.05 of probability. The data were transformed (square root) and the variables number of pods, number of seeds, seed weight of the cowpea cultivars, shoot fresh mass and shoot dry mass were submitted 
to analysis of variance, while the averages were compared by the Tukey test at $5 \%$ of probability, using the Assistat version 7.7 beta software (Silva \& Azevedo 2016).

\section{RESULTS AND DISCUSSION}

Under controlled conditions, there was a variation in the cycle of the cultivars: from 81 to 89 days for Canapu, 68 to 83 for BRS Marataoã, 66 to 78 for Pujante and 54 to 67 for BRS Tapaihum. For Canapu, the length of the vegetative phases (V3 and V4) varied 49 days, in average, when grown at $26^{\circ} \mathrm{C} / 20^{\circ} \mathrm{C}$, and 42 days when maintained at
$29{ }^{\circ} \mathrm{C} / 23{ }^{\circ} \mathrm{C}$ and $32{ }^{\circ} \mathrm{C} / 29{ }^{\circ} \mathrm{C}$. A decrease in the vegetative length was observed for BRS Marataoã and BRS Tapaihum with an increase in the temperature. Pujante presented an increase in the duration of the vegetative phase at the temperatures of $32{ }^{\circ} \mathrm{C} / 29^{\circ} \mathrm{C}$ (Table 1).

According to Rocha et al. (2017), the maturation cycles for Canapu, BRS Marataoã, BRS Pujante and BRS Tapaihum are 70-80, 70-75, 70-75 and 60-65, respectively. Evaluating the impacts of changes on the development and evapotranspiration of cowpea in the semi-arid region, Cavalcante Junior et al. (2016) stated that the temperature increase will cause a reduction of 14 to 23 days in the crop cycle. This

Table 1. Average length (days) of the phenological stages of the cowpea cultivars.

\begin{tabular}{|c|c|c|c|c|c|c|}
\hline \multirow{3}{*}{$\begin{array}{c}\text { Phenological } \\
\text { stages }\end{array}$} & \multicolumn{6}{|c|}{ Canapu } \\
\hline & \multicolumn{2}{|c|}{$26^{\circ} \mathrm{C} / 20^{\circ} \mathrm{C}$} & \multicolumn{2}{|c|}{$29^{\circ} \mathrm{C} / 23{ }^{\circ} \mathrm{C}$} & \multicolumn{2}{|c|}{$32^{\circ} \mathrm{C} / 29^{\circ} \mathrm{C}$} \\
\hline & $550 \mathrm{ppm}$ & $370 \mathrm{ppm}$ & $550 \mathrm{ppm}$ & $370 \mathrm{ppm}$ & $550 \mathrm{ppm}$ & $370 \mathrm{ppm}$ \\
\hline V3 & 15 & 12 & 10 & 12 & 10 & 10 \\
\hline V4 & 38 & 34 & 30 & 32 & 28 & 36 \\
\hline $\mathrm{R} 5$ & 15 & 21 & 20 & 15 & 25 & 21 \\
\hline R6 & 1 & 1 & 2 & 3 & 3 & 3 \\
\hline $\mathrm{R} 7$ & 9 & 10 & 9 & 9 & 6 & 10 \\
\hline $\mathrm{R} 8$ & 6 & 6 & 9 & 8 & 7 & 6 \\
\hline R9 & 5 & 1 & 2 & 2 & 5 & 3 \\
\hline Total length of the cycle & 89 & 85 & 82 & 81 & 84 & 89 \\
\hline & \multicolumn{6}{|c|}{ BRS Marataoã } \\
\hline V3 & 12 & 12 & 6 & 11 & 8 & 7 \\
\hline V4 & 34 & 32 & 28 & 23 & 21 & 22 \\
\hline R5 & 13 & 18 & 11 & 14 & 21 & 21 \\
\hline R6 & 3 & 2 & 3 & 2 & 2 & 5 \\
\hline R7 & 9 & 8 & 9 & 9 & 6 & 8 \\
\hline $\mathrm{R} 8$ & 6 & 8 & 9 & 6 & 7 & 3 \\
\hline R9 & 3 & 3 & 2 & 3 & 3 & 5 \\
\hline Total length of the cycle & 80 & 83 & 68 & 68 & 68 & 71 \\
\hline & \multicolumn{6}{|c|}{ BRS Pujante } \\
\hline V3 & 12 & 12 & 6 & 12 & 11 & 17 \\
\hline V4 & 20 & 24 & 28 & 23 & 26 & 27 \\
\hline R5 & 11 & 10 & 11 & 10 & 21 & 10 \\
\hline R6 & 2 & 3 & 3 & 2 & 2 & 2 \\
\hline R7 & 12 & 12 & 8 & 11 & 7 & 12 \\
\hline $\mathrm{R} 8$ & 12 & 11 & 8 & 5 & 7 & 8 \\
\hline R9 & 7 & 5 & 2 & 3 & 4 & 2 \\
\hline Total length of the cycle & 76 & 77 & 66 & 66 & 78 & 78 \\
\hline & \multicolumn{6}{|c|}{ BRS Tapaihum } \\
\hline V3 & 12 & 13 & 10 & 12 & 9 & 10 \\
\hline V4 & 19 & 18 & 13 & 13 & 10 & 14 \\
\hline R5 & 9 & 9 & 10 & 10 & 22 & 10 \\
\hline R6 & 3 & 2 & 2 & 2 & 2 & 2 \\
\hline R7 & 9 & 10 & 9 & 10 & 7 & 7 \\
\hline $\mathrm{R} 8$ & 10 & 6 & 7 & 8 & 5 & 6 \\
\hline R9 & 5 & 7 & 3 & 3 & 4 & 5 \\
\hline Total length of the cycle & 67 & 65 & 54 & 58 & 59 & 54 \\
\hline
\end{tabular}


happens because, with an increase in the temperature, an acceleration in the crop development occurs.

It was observed that the number of days for the beginning of the flowering stage (R6) were 60-67, 4760, 34-40 and 36-40 for Canapu, BRS Marataoã, BRS Pujante and BRS Tapaihum, respectively (Table 1). Mendonça et al. (2015), evaluating a field experiment with cowpea genotypes, verified a variation from 36 to 39 days. According to Freire Filho et al. (2005), temperature is one of the factors that may influence the beginning of the flowering stage. The authors emphasize that high temperatures alter the duration of the reproductive period and can promote flower abortion. In this present study, it was verified that the temperature increase leads to flower abortion for BRS Pujante and BRS Tapaihum, and only $33 \%$ and $66 \%$ of the plants produced pods at the temperatures of $32^{\circ} \mathrm{C} / 29^{\circ} \mathrm{C}$, in an environment enriched with $\mathrm{CO}_{2}$ (Table 2). High temperatures during the reproductive

Table 2. Percentage of flower abortion in cowpea cultivars submitted to different temperatures and $\mathrm{CO}_{2}$ concentration.

\begin{tabular}{llcc}
\hline \multicolumn{1}{c}{ Cultivar } & Temperature & $550 \mathrm{ppm}$ & $370 \mathrm{ppm}$ \\
\hline \multirow{4}{*}{ Canapu } & $26{ }^{\circ} \mathrm{C} / 20^{\circ} \mathrm{C}$ & $13 \%$ & $59 \%$ \\
& $29{ }^{\circ} \mathrm{C} / 23{ }^{\circ} \mathrm{C}$ & $50 \%$ & $42 \%$ \\
& $32{ }^{\circ} \mathrm{C} / 29^{\circ} \mathrm{C}$ & $60 \%$ & $23 \%$ \\
\hline \multirow{3}{*}{ BRS Marataoã } & $26{ }^{\circ} \mathrm{C} / 20^{\circ} \mathrm{C}$ & $59 \%$ & $34 \%$ \\
& $29{ }^{\circ} \mathrm{C} / 23{ }^{\circ} \mathrm{C}$ & $17 \%$ & $17 \%$ \\
& $32{ }^{\circ} \mathrm{C} / 29^{\circ} \mathrm{C}$ & $50 \%$ & $42 \%$ \\
\hline \multirow{3}{*}{ BRS Pujante } & $26{ }^{\circ} \mathrm{C} / 20{ }^{\circ} \mathrm{C}$ & $0 \%$ & $17 \%$ \\
& $29{ }^{\circ} \mathrm{C} / 23{ }^{\circ} \mathrm{C}$ & $33 \%$ & $17 \%$ \\
& $32{ }^{\circ} \mathrm{C} / 29^{\circ} \mathrm{C}$ & $67 \%$ & $42 \%$ \\
\hline \multirow{3}{*}{ BRS Tapaihum } & $26^{\circ} \mathrm{C} / 20^{\circ} \mathrm{C}$ & $8 \%$ & $0 \%$ \\
& $29{ }^{\circ} \mathrm{C} / 23{ }^{\circ} \mathrm{C}$ & $0 \%$ & $7 \%$ \\
& $32{ }^{\circ} \mathrm{C} / 29^{\circ} \mathrm{C}$ & $34 \%$ & $54 \%$ \\
\hline
\end{tabular}

stage show flower abortion, pollen and ovule infertility, impaired fertilization and, consequently, absence of pod formation (Sita et al. 2017).

This reduction, as a function of the temperature increase, was also observed in plants maintained at $370 \mathrm{ppm}$ of $\mathrm{CO}_{2}$. For BRS Marataoã, the plants kept at $29{ }^{\circ} \mathrm{C} / 23{ }^{\circ} \mathrm{C}$ presented the lowest percentage of flower abortion (Table 2). The increase in temperature plays an important role in the plant reproductive development. In addition to causing flower abortion, it may interfere with the viability of the pollen grain, on ovum fertility, with a direct effect on pod filling, seed size and, consequently, in grain yield (Sita et al. 2017). Heat stress during flowering may alter a series of physicochemical processes, including heat shock proteins, antioxidants, metabolites and hormones centered with sugar starvation (Liu et al. 2019). In this way, the advances to understand how the environmental elements interfere in the phenology of the plants contribute to the adoption of management strategies. In this study, it was verified that, despite the environmental conditions, the differentiation of the genotypes also influenced the duration of the crop cycle and the percentage of flower abortion. According to Mendonça et al. (2015), different genotypes play an important role in the cultivar cycle, because each one has a distinct thermal requirement.

In the summary of the analysis of variance using the mean square, it was verified that the interaction $\mathrm{CO}_{2} \mathrm{x}$ temperature $\mathrm{x}$ cultivar was not significant for number of pods, number of seeds and seed weight (Table 3). For these response variables, it was observed a significant difference only for the isolated factors (Table 3 ).

According to the results presented in Table 4, it is possible to verify a positive relationship with

Table 3. Summary of the analysis of variance for number of pods, number of seeds, seed weight, shoot fresh mass and shoot dry mass of cowpea cultivars submitted to different temperatures and carbon dioxide concentrations.

\begin{tabular}{lcccccc}
\hline & & \multicolumn{3}{c}{ Medium square } \\
\cline { 3 - 7 } Causes of variation & DF & $\begin{array}{c}\text { Number of } \\
\text { pods }\end{array}$ & $\begin{array}{c}\text { Number of } \\
\text { seeds }\end{array}$ & $\begin{array}{c}\text { Seed } \\
\text { weight }\end{array}$ & $\begin{array}{c}\text { Shoot fresh } \\
\text { mass }\end{array}$ & $\begin{array}{c}\text { Shoot dry } \\
\text { mass }\end{array}$ \\
\hline $\mathrm{CO}_{2}$ & 1 & $53.38^{* *}$ & $2,233.34^{*}$ & $191.37^{* *}$ & $1,687.60^{\text {ns }}$ & $263.79^{* *}$ \\
Temperature & 2 & $21.09^{*}$ & $2,181.79^{* *}$ & $257.64^{* *}$ & $14,823.23^{* *}$ & $113.56^{* *}$ \\
Cultivar & 3 & $196.79^{* *}$ & $13,267.83^{* *}$ & $414.39^{* *}$ & $4,544.68^{* *}$ & $114.84^{* *}$ \\
$\mathrm{CO}_{2}$ x temperature & 2 & $2.43^{\text {ns }}$ & $101.01^{\text {ns }}$ & $25.21^{\text {ns }}$ & $814.34^{\text {ns }}$ & $27.71^{\text {ns }}$ \\
$\mathrm{CO}_{2}$ x cultivar & 3 & $7.16^{\text {ns }}$ & $540.38^{\text {ns }}$ & $29.33^{\text {ns }}$ & $217.22^{\text {ns }}$ & $15.86^{\text {ns }}$ \\
Temperature x cultivar & 6 & $7.94^{\text {ns }}$ & $550.99^{\text {ns }}$ & $19.11^{\text {ns }}$ & $778.01^{\text {ns }}$ & $12.84^{\text {ns }}$ \\
$\mathrm{CO}_{2}$ x temperature x cultivar & 6 & $5.20^{\text {ns }}$ & $612.77^{\text {ns }}$ & $20.03^{\text {ns }}$ & $1,073.26^{\text {ns }}$ & $19.15^{\text {ns }}$ \\
\hline
\end{tabular}

* Significant at $5 \%$ of probability; ** significant at $1 \%$ of probability by the $\mathrm{F}$ test; ${ }^{\text {ns }}$ not significant. 
Table 4. Number of pods, number of seeds and seed weight of cowpea cultivars submitted to different temperatures and carbon dioxide concentrations.

\begin{tabular}{|c|c|c|c|}
\hline $\mathrm{CO}_{2}$ & Number of pods & Number of seeds & Seed weight \\
\hline $550 \mathrm{ppm}$ & $2.40 \mathrm{a}^{*}$ & $5.83 \mathrm{a}$ & $3.04 \mathrm{a}$ \\
\hline $370 \mathrm{ppm}$ & $2.04 \mathrm{~b}$ & $4.82 \mathrm{~b}$ & $2.47 \mathrm{~b}$ \\
\hline Temperature & Number of pods & Number of seeds & Seed weight \\
\hline $26^{\circ} \mathrm{C} / 20^{\circ} \mathrm{C}$ & $2.01 \mathrm{~b}$ & $4.55 \mathrm{~b}$ & $2.21 \mathrm{~b}$ \\
\hline $29^{\circ} \mathrm{C} / 23^{\circ} \mathrm{C}$ & $2.445 \mathrm{a}$ & $6.29 \mathrm{a}$ & $3.34 \mathrm{a}$ \\
\hline $32^{\circ} \mathrm{C} / 29^{\circ} \mathrm{C}$ & $2.20 \mathrm{ab}$ & $5.13 \mathrm{ab}$ & $2.70 \mathrm{~b}$ \\
\hline Cultivars & Number of pods & Number of seeds & Seed weight \\
\hline BRS Tapaihum & $3.17 \mathrm{a}$ & $8.54 \mathrm{a}$ & $3.88 \mathrm{a}$ \\
\hline BRS Marataoã & $1.99 \mathrm{~b}$ & $5.07 \mathrm{~b}$ & $2.52 \mathrm{~b}$ \\
\hline BRS Pujante & $2.24 \mathrm{~b}$ & $4.57 \mathrm{bc}$ & $2.79 \mathrm{~b}$ \\
\hline Canapu & $1.49 \mathrm{c}$ & $3.119 \mathrm{c}$ & $1.82 \mathrm{c}$ \\
\hline $\mathrm{CV}(\%)$ & 23.55 & 34.17 & 25.79 \\
\hline
\end{tabular}

the increase in the carbon dioxide concentration and number of pods, number of seeds and seed weight.

The increase in the $\mathrm{CO}_{2}$ concentration favors the photosynthesis rate, since carbon dioxide is the primary substrate for photosynthesis, leading to a higher plant growth (Martinez et al. 2015, Taiz et al. 2017). Dorneles et al. (2019) observed that, in wheat, an environment enriched with carbon dioxide increases the agronomic performance of the crop by means of physiological changes, biomass gain and increase in grain yield. In this study, the fertilizing effect of carbon dioxide was also observed, such as the increase in the number of pods, number of seeds and seed weight.

The effect of the temperature was also observed in an isolated manner. Plants kept at $29{ }^{\circ} \mathrm{C} / 23{ }^{\circ} \mathrm{C}$ (day/night) and at $32{ }^{\circ} \mathrm{C} / 29^{\circ} \mathrm{C}$ presented the highest number of pods and seeds. The highest seed weight was observed in plants kept at $29^{\circ} \mathrm{C} / 23^{\circ} \mathrm{C}$ (Table 4). According to Andrade Júnior et al. (2017), the suitable temperature for the development of cowpea is in the range of $18{ }^{\circ} \mathrm{C}$ to $34{ }^{\circ} \mathrm{C}$. Temperatures below $19{ }^{\circ} \mathrm{C}$ delay the appearance of flowers, besides increasing the crop cycle (Andrade Júnior et al. 2017). Thus, the temperature directly influenced the number of seeds per pod and seed weight. In California, the increase of $1{ }^{\circ} \mathrm{C}$ in the nighttime temperature resulted in a reduction of $4 \%$ to $14 \%$ in pod yield and grain yield, due to pollen sterility (Hall 2004).

Regarding the cultivars, BRS Tapaihum differed statistically from the others, presenting a higher number of pods, number of seeds and seed weight (Table 4). Canapu presented the lowest values for number of pods and seed weight (Table 4).
For the shoot fresh and dry mass, it was verified, in the summary of the analysis of variance, that the interaction $\mathrm{CO}_{2} \times$ temperature $\mathrm{x}$ cultivar was not significant (Table 3). The shoot fresh mass only influenced the isolated temperature and cultivar variables. The highest shoot fresh mass values were observed in plants maintained at $29{ }^{\circ} \mathrm{C} / 23^{\circ} \mathrm{C}$ and $32{ }^{\circ} \mathrm{C} / 29^{\circ} \mathrm{C}$. The same was observed for shoot dry mass. In relation to the effect of increasing the $\mathrm{CO}_{2}$ concentration, the highest shoot dry mass was observed in plants maintained at 550 ppm of $\mathrm{CO}_{2}$. Regarding the cultivars, BRS Pujante presented the highest shoot fresh and dry mass, when compared to BRS Tapaihum (Table 5).

An increased $\mathrm{CO}_{2}$ concentration may provide a higher biomass production (Martinez et al. 2015).

Table 5. Shoot fresh mass (SFM) and shoot dry mass (SDM) of cowpea cultivars submitted to different temperatures and carbon dioxide concentrations.

\begin{tabular}{ccc}
\hline $\mathrm{CO}_{2}$ & SFM & SDM \\
\hline $550 \mathrm{ppm}$ & $87.56 \mathrm{a}^{*}$ & $13.58 \mathrm{a}$ \\
$370 \mathrm{ppm}$ & $77.87 \mathrm{a}$ & $9.75 \mathrm{~b}$ \\
\hline Temperature & $\mathrm{SFM}$ & $\mathrm{SDM}$ \\
\hline $26^{\circ} \mathrm{C} / 20^{\circ} \mathrm{C}$ & $55.36 \mathrm{~b}$ & $9.18 \mathrm{~b}$ \\
$29^{\circ} \mathrm{C} / 23^{\circ} \mathrm{C}$ & $88.87 \mathrm{a}$ & $13.25 \mathrm{a}$ \\
$32^{\circ} \mathrm{C} / 29^{\circ} \mathrm{C}$ & $103.91 \mathrm{a}$ & $12.56 \mathrm{a}$ \\
\hline Cultivars & $\mathrm{SFM}$ & $\mathrm{SDM}$ \\
\hline BRS Tapaihum & $63.16 \mathrm{~b}$ & $8.88 \mathrm{c}$ \\
BRS Marataoã & $87.78 \mathrm{ab}$ & $12.63 \mathrm{ab}$ \\
BRS Pujante & $101.02 \mathrm{a}$ & $14.67 \mathrm{a}$ \\
Canapu & $78.89 \mathrm{ab}$ & $10.48 \mathrm{bc}$ \\
\hline $\mathrm{CV}(\%)$ & 37.77 & 35.41 \\
\hline
\end{tabular}

* Means followed by the same letter do not differ statistically by the Tukey test at $5 \%$ of probability. 
This is due to the fertilizer effect of the higher photosynthetic activity, with a decrease in the photorespiration and transpiration rates (Walter et al. 2015). Dorneles et al. (2019), when studying the effect of increasing $\mathrm{CO}_{2}$ concentrations, also verified the fertilizer effect of this gas on wheat plants, with an increase in dry matter. A similar result was observed in this study, where the dry mass is higher in the plant in an environment enriched with carbon dioxide.

Climate change poses a major challenge for humanity. Thus, studies on impacts on the agricultural production are of great importance, since they directly reflect on food security (FAO 2019). In this sense, new studies will need to be carried out, including the interaction with the water element. Responses obtained under controlled conditions will help to improve and redefine crop management strategies, in order to not compromise the sustainability of the production system.

\section{CONCLUSIONS}

1. Temperature affects the development of cowpea cultivars, and the temperatures of $29^{\circ} \mathrm{C}$ (day)/ $23{ }^{\circ} \mathrm{C}$ (night) lead to a higher seed weight;

2. The increase of the $\mathrm{CO}_{2}$ concentration increases the number of pods, number of seeds and seed weight, with BRS Tapaihum showing the highest rates;

3. The temperatures of $32^{\circ} \mathrm{C}$ (day) $/ 29^{\circ} \mathrm{C}$ (night) lead to flower abortion in the BRS Pujante and BRS Tapaihum cultivars.

\section{REFERENCES}

ALIYU, O. M.; LAWAL, O. O.; WAHAB, A. A.; IBRAHIM, U. Y. Evaluation of advanced breeding lines of cowpea (Vigna unguiculata L. Walp) for high seed yield under farmers' field conditions. Plant Breeding and Biotechnology, v. 7, n. 1, p. 12-23, 2019.

ANDRADE JÚNIOR, A. S. de; BASTOS, E. A.; CARDOSO, M. J. Clima. In: BASTOS, E. A. (org.). Cultivo de feijão-caupi. Brasília, DF: Embrapa, 2017. Available at: https://ainfo.cnptia.embrapa.br/digital/bitstream/ item/161161/1/SistemaProducaoCaupiCapituloClima.pdf. Access on: 01 July 2019.

CAVALCANTE JUNIOR, E. G.; MEDEIROS, J. F.; ESPÍNOLA SOBRINHO, J.; FIGUEIRÊDO, V. B.; COSTA, J. P. N; SANTOS, W. O. Development and water requirements of cowpea under climate change conditions in the Brazilian semi-arid region. Revista Brasileira de Engenharia Agrícola e Ambiental, v. 20, n. 9, p. 783-788, 2016.

CHALLINOR, A. J.; WATSON, J.; LOBELL, D. B.; HOWDEN, S. M.; SMITH, D. R.; CHHETRI, N. A meta-analysis of crop yield under climate change and adaptation. Natural Climate Change, v. 4, n. 1, p. 287291, 2014.

DORNELES, K. R.; POSSO, D. A.; REBHAHN, I.; DEUNER, S.; PAZDIORA, P. C.; ÁVILA, L. A.; DALLAGNOL, L. J. Respostas morfofisiológicas e rendimento de grãos do trigo mediados pelo aumento da concentração de $\mathrm{CO}_{2}$ atmosférico. Revista Brasileira de Ciências Agrárias, v. 14, n. 1, p. 1-7, 2019.

FANCELLI, A. L. Feijão: tópicos especiais de manejo. Piracicaba: ESALQ/USP/LPV, 2009.

FOOD AND AGRICULTURAL ORGANIZATION OF THE UNITED NATIONS (FAO). Cambio climático y seguridad alimentaria y nutricional en América Latina y el Caribe. Santiago: FAO, 2019.

FREIRE FILHO, F. R.; LIMA, J. A. de A.; RIBEIRO, V. Q. Feijão-caupi: avanços tecnológicos. Brasília, DF: Embrapa Informação Tecnológica, 2005.

HALL, E. H. Breeding for adaptation to drought and heat in cowpea. European Journal of Agronomy, v. 21, n. 4, p. 447-454, 2004.

HATFIELD, J. L.; PRUEGER, J. H. Temperature extremes: effect on plant growth and development. Weather and Climate Extremes, v. 10, n. 1, p. 4-10, 2015.

INTERGOVERNMENTAL PANEL ON CLIMATE CHANGE (IPCC). Climate change 2013: the physical science basis: summary for policymakers. Genebra: IPCC, 2013.

LIU, Y.; LI, J.; ZHU, Y.; JONES, A.; ROSE, R. J.; SONG, Y. Heat stress in legume seed setting: effects, causes, and future prospects. Frontiers in Plant Science, v. 10, n. 938, p. 1-12, 2019.

MARTINEZ, C. A.; OLIVEIRA, E. A. D.; MELLO, T. R. P.; ALZATE-MARIN, A. L. Respostas das plantas ao incremento atmosférico de dióxido de carbono e da temperatura. Revista Brasileira de Geografia Física, v. 8, n. especial VI SMUD, p. 635-650, 2015.

MENDONÇA, C. A.; BARROSO NETO, A. M.; BERTINI, C. H. C. de M.; AMORIM, M. Q.; ARAÚJO, L. B. R. Caracterização fenológica associada a graus-dia em genótipos de feijão-caupi para produção de grãos verdes. Enciclopédia Biosfera, v. 11, n. 21, p. 485-493, 2015 . 
ROCHA, M. de M.; SILVA, K. J. D. de; FREIRE FILHO, F. R.; MENEZES JUNIOR, J. A. de. Cultivares. In: BASTOS, E. A. (org.). Cultivo de feijão-caupi. Brasília, DF: Embrapa, 2017. Available at: https://ainfo. cnptia.embrapa.br/digital/bitstream/item/161165/1/ SistemaProducaoCaupiCapituloCultivares.pdf. Access on: 01 July 2019.

SILVA, F. A. S.; AZEVEDO, C. A. V. The Assistat software version 7.7 and its use in the analysis of experimental data. African Journal of Agricultural Research, v. 11, n. 39, p. 3733-3740, 2016.

SITA, K.; SEHGAL, A.; HANUMANTHARAO, B.; NAIR, R. M.; PRASAD, P. V. V.; KUMAR, S.; GAUR, P. M.; FAROOQ, M.; SIDDIQUE, K. H. M.; VARSHNEY, R. K.; NAYYAR, H. Food legumes and rising temperatures: effects, adaptive functional mechanisms specific to reproductive growth stage and strategies to improve heat tolerance. Frontiers in Plant Science, v. 8, n. 1, p. 1-30, 2017.
SRIVASTAVA, D.; SHAMIM, M. D.; KUMAR, M.; MISHRA, A.; MAURYA, R.; SHARMA, D.; PANDEY, K. N. S. Role of circadian rhythm in plant system: an update from development to stress response. Environmental and Experimental Botany, v. 162, n. 1, p. 256-271, 2019.

TAIZ, L.; ZEIGER, E.; MOLLER, I. M.; MURPHY, A. Fisiologia e desenvolvimento vegetal. 6. ed. Porto Alegre: Artmed, 2017.

TANS, P.; KEELING, R. ESRL global monitoring division and global greenhouse gas reference network. 2017. Available at: http://www.esrl.noaa.gov/gmd/ccgg/trends/. Access on: 10 May 2019.

VALE, J. C. do; BERTINI, C.; BORÉM, A. Feijão-caupi: do plantio à colheita. Viçosa: Ed. UFV, 2017.

WALTER, L. C.; ROSA, H. T.; STRECK, N. A. Mecanismos de aclimatação das plantas à elevada concentração de $\mathrm{CO}_{2}$. Ciência Rural, v. 45, n. 90, p. 15641571, 2015. 